member of the National Leadership Committee of Title VI Center Directors. Albert Dien observed that in the Directors' conferences, "Jack always took an active role, as much a critic of policies he viewed as misconceived as he was a leader in discussions. ... His opinions carried much weight."

Personally I have to say that Jack has left a void. I will remember him for his creative work as a Center Director willing always to help his much challenged colleague in the South Asia Center; for his enormous store of humor, whether applied to reinforcing and enabling good scholarship or puncturing the gaseous balloons of academic bureaucrats and other self-promoters; for his special talent suggesting new titles (heavy with puns) for colleagues' papers at the History Research Group; and for his deep personal love and pride in the wonderful family raised with his wife Peg. He regarded their accomplishments with as great a satisfaction as any of the glittering prizes of academe.

Jack is survived by his wife Peg, two daughters, a son and their families.

Condolences may be sent to them at: 3631 N.E. 85 th Street, Seattle, WA 98115 .

FRANK F. CONLON University of Washington

\title{
CHARLES O. HUCKER
}

$$
1919-1994
$$

Charles O. Hucker, University of Michigan professor emeritus of Chinese and of history, died November 14, 1994, in Odessa, Texas. He was 75 years old.

One of the foremost historians of Imperial China and a leading promoter of academic programs in Asian Studies during the 1950s and 1960s, Hucker retired from the U-M in 1983. In his honor, the University established the Charles O. Hucker professorship in the U-M Department of Asian Languages and Cultures.

Hucker authored, among other works, "A Dictionary of Official Titles in Imperial China," the most comprehensive guide to traditional Chinese government in a Western language, and "China's Imperial Past," an acclaimed general history of Imperial China. He also contributed to Encyclopedia Britannica, Encyclopedia Americana, and the Cambridge History of China.

Born in St. Louis on June 21, 1919, Hucker graduated from the University of Texas, and served in the Army Air Corps during World War II where he achieved the rank of major and was awarded the Bronze Star. He earned a Ph.D. degree in Chinese from the University of Chicago, was a Rockefeller Foundation fellow, a senior fellow of the National Endowment for the Humanities, and a frequent consultant to the U.S. Office of Education, foundations, and colleges and universities. He received an honorary doctorate of humanities from Oakland University in 1974.

Prior to joining the U-M in 1965 where he chaired the Department of Far Eastern Languages and Literatures, Hucker taught at the University of Chicago, the University of Arizona, and Oakland University.

Throughout his teaching career, he was an active member of many professional associations. He was among a small number of American China historians who 
visited scholarly centers in China in 1979 under joint auspices of the U.S. National Academy of Sciences and the Chinese Academy of Social Sciences.

In his retirement, Hucker and his wife, the former Myrl Henderson, whom he married in 1943, lived in Tucson, Arizona, where he volunteered in schools and hospitals and wrote plays and short stories, several of which have been published or produced. In addition to his wife, Hucker is survived by a brother and a sister. 